\title{
RANCANG BANGUN PENILAIAN HASIL PEMBELAJARAN SISWA SEKOLAH DASAR BERBASIS KURTILAS
}

\author{
Enang Rusnandi \\ Teknik Informatika, Fakultas Teknik, Universitas Majalengka \\ derusnandi@yahoo.com
}

\begin{abstract}
Abstraksi
Pengembangan Kurikulum 2013 dilaksanakan atas dasar beberapa prinsip standar kompetensi lulusan diturunkan dari kebutuhan, standar isi diturunkan dari standar kompetensi lulusan melalui kompetensi inti yang berbasis mata pelajara, semua mata pelajaran harus berkontribusi terhadap pembentukan sikap, keterampilan, dan pengetahuan peserta didik, mata pelajaran diturunkan dari kompetensi yang ingin dicapai, semua mata pelajaran diikat oleh kompetensi inti, keselarasan tuntutan kompetensi lulusan, isi, proses pembelajaran, dan penilaian. Artikel ini ditulis setelah melalui beberapa kegiatan ilmiah, yaitu melakukan proses pendalaman permasalahan, analisis, desain dan implementasi pemograman. Dampak dari pelaksanaan kurtilas ini adalah pada proses pembelajaran diantaranya adalah adanya keharusan guru membuat rencana pembelajaran sesuai dengan tema-tema yang telah ditentukan, dengan sedikit mengesampingkan nama-nama mata pelajaran. Artinya bahwa pada satu kali pertemuan di kelas, beberapa mata pelajaran disampaikan, dengan batasan bahwa tema yang disampaikan harus sama. Pada bidang penilaian, terjadi beberapa perubahan signifikan, yaitu diantaranya bahwa nilai akhir siswa harus dalam bentuk kualitatif.
\end{abstract}

Keywords: kurtilas, pembelajaran, penilaian kualitatif, analisis, desain, dan implementasi.

\section{PENDAhuluan}

\section{A. Latar Belakang Masalah}

Pengembangan kurtilas atau kurikulum 2013 dilakukan untuk menyempurnakan kurikulum sebelumnya, dimana penyermpurnaan ini terutama ditekankan pada hal pola pikir, penguatan tata kelola kurikulum, pendalaman dan perluasan materi, penguatan proses pembelajaran, dan penyesuaian beban belajar agar dapat menjamin kesesuaian antara apa yang diinginkan dengan apa yang dihasilkan. Penyempurnaan pola pikir mengandung makna adanya kehendak pemerintah agar para pihak pengelola pendidikan memiliki kesamaan pandang terhadap permasalahan dan pelaksanaan pendidikan. Proses dan hasil pengembangan kurikulum menjadi amat penting untuk dilakukan, sejalan dengan kontinuitas kemajuan ilmu pengetahuan, teknologi, dan seni budaya serta perubahan masyarakat pada tataran lokal, nasional, regional, dan global di masa depan. Terlebih lagi saat ini kita sedang menghadapi sebuah tantangan global menghadapi program MEA (Masyarakat Ekonomi ASEAN), sehingga aneka kemajuan dan perubahan itu melahirkan tantangan internal dan eksternal di bidang pendidikan. Karena itu, upaya bertahap untuk melakukan implementasi Kurikulum 2013 merupakan langkah strategis dalam menghadapi globalisasi dan tuntutan masyarakat Indonesia masa depan.

Pengembangan Kurikulum 2013 dilaksanakan atas dasar beberapa prinsip utama, yaitu sebagai berikut : Pertama, standar kompetensi lulusan diturunkan dari kebutuhan. Kedua, standar isi diturunkan dari standar kompetensi lulusan melalui kompetensi inti yang berbasis mata pelajaran. Ketiga, semua mata pelajaran harus berkontribusi terhadap pembentukan sikap, keterampilan, dan pengetahuan peserta didik. Keempat, mata pelajaran diturunkan dari kompetensi yang ingin dicapai. Kelima, semua mata pelajaran diikat oleh kompetensi inti. Keenam, keselarasan tuntutan kompetensi lulusan, isi, proses pembelajaran, dan penilaian

Pada tataran teknis di sekolah, pelaksanaan kurikulum 2013 telah berdampak pada beberapa hal yang menyangkut masalah proses pembelajaran dan penilaian. Hal tersebut tentu 
saja sesuai dengan tuntutan dan pedoman implementasi kurikulum 2013. Dampak pada proses pembelajaran diantaranya adalah adanya keharusan guru membuat rencana pembelajaran sesuai dengan tema-tema yang telah ditentukan, dengan sedikit mengesampingkan nama-nama mata pelajaran. Artinya bahwa pada satu kali pertemuan di kelas, beberapa mata pelajaran disampaikan, dengan batasan bahwa tema yang disampaikan harus sama. Pada bidang penilaian, terjadi beberapa perubahan signifikan, yaitu diantaranya bahwa nilai akhir siswa harus dalam bentuk kualitatif.

Berdasarkan hal tersebut di atas, maka penulis melalui artikel ini bermaksud memberikan paparan mengenai implementasi penilaian hasil pembelajaran siswa berbasis kurtilas.

\section{B. Identifikasi Masalah}

Beberapa identifikasi terhadap permasalahan yang berhubungan dengan implementasi kurikulum 2013 ini adalah sebagai berikut :

1) Pada kurikulum 2013 terdapat muatan visi tematik yang harus melandasi proses pembelajaran di kelas.

2) Pelaksanaan kurikulum 2013 menuntut adanya kreativitas dan wawasan yang luas dari unsur guru.

3) Guru di dalam kurikulum 2013 berkedudukan sebagai fasilitator di kelas.

4) Proses pemberian nilai hasil pembelajaran siswa dilakukan pada setiap akhir penyampaian sub tema pelajaran.

5) Penilaian siswa yang berbasis kurikulum 2013 dilaksanakan berdasarkan hasil rekap beberapa ranah dalam pendidikan, meliputi ranah pengetahuan, sikap dan keterampilan.

\section{Rumusan Masalah}

1) Bagaimana bentuk penilaian hasil pembelajaran siswa Sekolah Dasar yang sesuai dengan format kurtilas?

2) Bagaimana desain yang bisa dibuat untuk membuat penilaian hasil pembelajaran siswa Sekolah Dasar berbasis kurtilas.

3) Bagaimana implementasi hasil rancangan penilaian hasil pembelajaran siswa berbasis kurtilas yang bisa digunakan oleh guru.
Penilaian hasil pembelajaran siswa dilakukan untuk semua jenjang kelas di Sekolah Dasar.

\section{E. Lokasi Penelitian \\ Sekolah Dasar Negeri Cigasong Kabupaten Majalengka.}

\section{F. Tujuan Penelitian}

Tujuan dari pembuatan penelitian ini adalah :

1) Memberikan gambaran mengenai penilaian siswa berbasis kurtilas

2) Memberikan gambaran mengenai hasil analisis dan desain penilaian pembelajaran berbasis kurtilas.

\section{G. Metodologi Pengembangan Sistem}

Metodologi pengembangan sistem yang digunakan adalah waterfall atau SDLC (System Development Life Cycle), dengan tahapan sebagai berikut :

1) Pre-investigation / Requirement definition

2) System and software design

3) Implementing and unit testing

4) Integration and system testing

5) Operation and maintenance

Waterfall menurut referensi Sommerville dapat digambarkan seperti berikut ini :

1. Requirement Analysis Definition, mengumpulkan kebutuhan secara lengkap kemudian di analisis, didefinisikan kebutuhan program yang akan dibangun, fase ini harus dikerjakan secara lengkap untuk bisa menghasilkan desain yang lengkap.

2. System and Software Desain (perancangan sistem dan perangkat lunak), fase ini dikerjakan setelah fase sebelumnya selesai. Proses perancangan sistem membagi persyaratan dalam sistem perangkat keras atau perangkat lunak. Menentukan arsitektur sistem secara keseluruhan.

3. Implementation and Unit System (implementasi dan pengujian), desain program diterjemahkan kedalam kode-kode dengan menggunakan bahasa pemograman yang sudah ditentukan.perancangan perangkat lunak direalisasikan sebagai serangkaian program atau unit program. Pengujian unit melibatkan verifikasi bahwa setiap unit telah memenuhi spesifikasinya.

\section{Batasan Masalah}


4. Integration and system Testing (integrasi dan pengujian sistem), penyatuan unit program kemudian uji secara keseluruhan. Unit program atau program individual diintegrasikan dan diuji sebagai sistem yang lengkap untuk menjamin bahwa persyaratan sistem telah dipenuhi.

5. Operation and Maintenance (operasi dan pemeliharaan), mengoperasikan program dilingkungannya dan melakukan pemeliharaan seperti menyesuaikan/perubahan dengan situasi sebenarnya. Pemeliharaan mencakup koreksi dan berbagai error yang tidak ditemukan pada tahap-tahap sebelumnya, perbaikan atas implementasi unit sistem dan pengembangan pelayanan sistem.

\section{KAJIAN LITERATUR}

\section{A. Pengembangan Kurikulum 2013}

Kurikulum sebagaimana yang ditegaskan dalam Pasal 1 Ayat (19) Undang-undang Nomor 20 Tahun 2003 adalah seperangkat rencana dan pengaturan mengenai tujuan, isi, dan bahan pelajaran serta cara yang digunakan sebagai pedoman penyelenggaraan kegiatan pembelajaran untuk mencapai tujuan pendidikan tertentu. Pengembangan Kurikulum 2013 merupakan langkah lanjutan Pengembangan Kurikulum Berbasis Kompetensi yang telah dirintis pada tahun 2004 dan KTSP 2006 yang mencakup kompetensi sikap, pengetahuan, dan keterampilan secara terpadu.

\section{B. Landasan Kurikulum 2013}

Kurikulum 2013 dikembangkan berdasarkan ketentuan yuridis yang mewajibkan adanya pengembangan kurikulum baru, landasan filosofis, dan landasan empirik. Landasan yuridis merupakan ketentuan hukum yang dijadikan dasar untuk pengembangan kurikulum dan yang mengharuskan adanya pengembangan kurikulum baru. Yaitu: Landasan Yuridis; Landasan Filosofis ; Landasan Empiris dan Landasan Teoritik.

\section{Karakteristik Kurikulum 2013}

Kurikulum 2013 adalah kurikulum berbasis kompetensi. Kurikulum berbasis kompetensi adalah outcomes-based curriculum dan oleh karena itu pengembangan kurikulum diarahkan pada pencapaian kompetensi yang dirumuskan dari SKL. Demikian pula penilaian hasil belajar dan hasil kurikulum diukur dari pencapaian kompetensi. Keberhasilan kurikulum dartikan sebagai pencapaian kompetensi yang dirancang dalam dokumen kurikulum oleh seluruh peserta didik.

\section{Tuntutan Kurikulum 2013}

Asesmen autentik memiliki relevansi kuat terhadap pendekatan ilmiah dalam pembelajaran sesuai dengan tuntutan Kurikulum 2013. Peserta didik diminta untuk merefleksikan dan mengevaluasi kinerja mereka sendiri dalam rangka meningkatkan pemahaman yang lebih dalam tentang tujuan pembelajaran serta mendorong kemampuan belajar yang lebih tinggi. Pada asesmen autentik guru menerapkan kriteria yang berkaitan dengan konstruksi pengetahuan, kajian keilmuan, dan pengalaman yang diperoleh dari luar sekolah.

\section{E. Konsep Dasar Sistem}

Ada dua kelompok pendekatan di dalam mendefinisikan sistem yaitu menekankan pada prosedurnya dan menekankan pada komponen atau elemenya. Pendekatan sistem yang lebih menekankan pada prosedurnya. Sehingga dapat disimpulkan bahwa sistem adalah suatu kesatuan yang terdiri dari dua atau lebih komponen atau subsistem yang berhubungan untuk mencapai suatu tujuan.

\section{F. Analisis Sistem}

Analisis sistem adalah penguraian dari suatu sistem informasi yang utuh ke dalam bagianbagian komponennya dengan maksud untuk mengidentifikasikan dan mengevaluasi permasalahan - permasalahan, kesempatan kesempatan, hambatan - hambatan yang terjadi dan kebutuhan-kebutuhan yang diharapkan sehingga dapat diusulkan perbaikanperbaikannya(Jogiyanto H.M, 2001 : 29)

Langkah-langkah dasar yang harus dilakukan oleh analisis sistem menurut (Jogiyanto H.M., 2001 : 29) adalah sebagai berikut :

a. Identify, yaitu mengidentifikasi masalah

b. Understand, yaitu memahami kerja sistem yang ada

c. Analyzc, yaitu menganalisa sistem

d. Report, yaitu membuat laporan 
Tahap analisis merupakan tahap yang kritis yang sangat penting, karena kesalah dalam tahap ini akan menyebabkan juga kesalahan ditahap selanjutnya.

Alat yang digunakan dalam analisa sistem secara terstruktur yaitu Data Flow Diagram (DFD), kamus data dan hubungan entitas.

\section{G. Konsep Dasar Informasi}

Informasi adalah data yang diolah menjadi bentuk yang lebih berguna dan berarti bagi yang menerimanya."(Jogiyanto HM, 2001:8) Sumber informasi adalah data, data merupakan fakta atau pernyataan yang menggambarkan suatu kejadian nyata, kemudian dirumuskan kedalam sekelompok simbol atau lambanglambang tertentu yang menunjukan kualitas, tindakan atau hal-hal lain. ( http://elib.unikom.ac.id)

\section{H. Konsep Dasar Sistem Informasi}

Menurut Robert A.Leitch dan K. Roscoe Davis, sistem informasi adalah, "Suatu sistem didalam suatu organisasi yang mempertemukan kebutuhan pengolahan transaksi harian, mendukung operasi, bersifat manajerial dan kegiatan strategi dari suatu organisasi, menyediakan kepada pihak luar akan laporanlaporan yang diperlukan". (http://willis.comze.com/pengertian_si.html)

Sistem informasi, dapat diluhat dari keterkaitan antara data dan informasi sebagai entitas penting pembentuk sistem informasi. Data merupakan nilai, keadaan, atau sifat yang berdiri sendiri lepas dari konteks apapun. Sementara informasi adalah data yang telah diolah menjadi sebuah bentuk yang berarti bagi penerimanya dan bermanfaat dalam pengambilan keputusan saat ini atau mendatang (Davis, 1995). Informasi adalah data yang telah diproses, atau data yang memiliki arti (Mc Leod, 1995).

Menurut pendapat Davis (1995) komponen sistem informasi sebagai berikut:

1. Perangkat keras komputer (hardware)

2. Perangkat lunak (software) yang terdiri dari perangkat lunak sistem umum, perangkat lunak terapan, dan program aplikasi.

3. Database.

4. Prosedur.

5. Petugas operasional.

\section{Konsep Dasar Sistem Basis Data}

Merupakan suatu sistem untuk menyususn dan mengelola record-record menggunakan komputer untuk menyimpan atau merekam serta memelihara data operasional lengkap sebuah organisasi/perusahaan/intansi sehingga mampu menyediakan informasi yang optimal yang diperlukan pemakai untuk proses mengambil keputusan.

Terdapat empat komponen dasar sistem basis data, yaitu :

1. Data

2. Hardware

3. Software

4. User atau Pemakai

\section{J. Diagram Konteks}

Diagram konteks merupakan langkah awal dari analisis struktur dan level teratas dari diagram arus data dan merupakan penggambaran sistem secara garis besar. Diagram konteks menggambarkan hubungan aliran-aliran data kedalam dan keluar sistem atau entitas-entitas yang terletak diluar sistem (output) atau menerima data dari sistem tersebut (input).

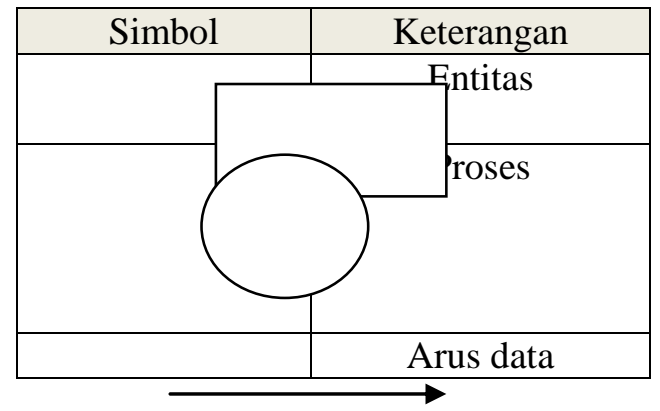

Gambar 1: Diagram Kontek

\section{K. Data Flow Diagram}

Data Flow Diagram adalah sebuah representasi grafik dari sebuah sebuah sistem. DFD menggambarkan sebuah sistem beserta komponen - komponennya. DFD dapat dibagi menjadi 3 bagian, yaitu : Context Diagram ; DFD Fisik dan DFD Logis.

\section{Flow Map}

Flowmap merupakan prosedur kerja atau Functional Flowchart (Diagram Alir Fungsional). FlowMap/Functional FlowChart 
merupakan diagram alir yang menggambarkan pergerakan proses diantara unit kerja yang berbeda-beda, sekaligus menggambarkan arus dari dokumen, aliran data fisik, entitas-entitas sistem informasi dan kegiatan operasi yang berhubungan dengan sistem infomasi.

Flowmap adalah alur dokumen yang mengalir dari satu entitas ke entitas yang lain. Entitas terbagi dua yaitu :

1. Entitas Luar (Eksternal Entity) Yaitu entitas yang memberikan Input dan menerima Output dari sistem.

2. Entitas Dalam (Internal Entity) Yaitu entitas yang menerima Input, melakukan pemprosesan dengan komputerisasi dan meghasilkan Output.

1. Simbol-simbol yang digunakan dalam FlowMap :

2. Dokumen adalah data-data yang mengalir di dalam sistem informasi. Dokumen dengan dokumen dalam satu kolom, tidak dihubungkan secara langsung.

3. Proses pengolahan data (komputerisasi). Proses yang terjadi dengan menggunakan perangkat komputer (komputerisasi).

4. Disk atau database. Kumpulan data yang saling berhubungan yang disimpan secara bersama sedemikian rupa dan tanpa pengulangan (redudansi) yang tidak perlu, untuk memenuhi berbagai kebutuhan.

\section{M.Bagan Alur (Flowchart)}

Flowchart atau bagan alur merupakan metode untuk menggambarkan tahap-tahap penyelesaian masalah (prosedure) beserta aliran data dengan simbol-simbol standar yang mudah dipahami. Dalam sehari-hari flowchart sering digunakan di pusat-pusat layanan seperti kantor pemerintahan, bank, rumah sakit, organisasi masyarakat dan perusahaan.

Tujuan utama penggunaan flowchart adalah untuk menyederhanakan rangkaian proses atau prosedur untuk memudahkan pemahaman pengguna terhadap informasi tersebut. Untuk itu, desain sebuah flowchart harus ringkas, jelas, dan logis.

Flowchart menggunakan berbagai simbol yang terstandarisasi secara internasional. Hal ini ditunjukan untuk memudahkan setiap orang memahami berbagai variasi floechart. Secara khusus, bagian ini akan memaparkan simbolsimbol penting dalam pembuatan flowchart.

\section{N. Entity Relationship Diagram}

Entity Relationship Diagram (ERD) merupakan diagram yang digunakan untuk merancang suatu basis data, yang dapat melihat hubungan atau relasi antara entity atau objek yang terlibat beserta atributnya.

1. Entitas/Entity merupakansuatu hal atau objek yang dapat dibedakan dengan yang lain (Unique).

2. Atribut merupakan karakteristik dari suatu entitas.

3. Relasi merupakan hubungan antara satu entitas dengan entitas lainnya.

Derajat relasi adalah jumlah entitas yang berpartisipasi dalam suatu relationship. Derajat relationship terdiri dari :

1. Binary relationship merupakan keterhubungan antara dua tipe entitas.

2. Terany Relationship merupakan keterhubungan antara tiga tipe entitas.

3. Quanternary Relationship merupakan keterhubungan natara empat tipe entitas.

Simbol Yang Digunakan Dalam Entity Relationship Diagram(ERD), sebagai berikut :

III. TINJAUAN UMUM DAN ANALISIS

\section{A. Visi Dinas Pendidikan}

Untuk mencapai Visi Pemerintah Kabupaten Majalengka maka Dinas Pendidikan menetapkan Visi Dinas Pendidikan untuk kurun waktu 5 (lima) tahun kedepan yakni: "Terwujudnya Masyarakat Majalengka Yang Cerdas Dan Kompetitif Berbasis Agamis”.

Visi Dinas Pendidikan lebih menekankan kepada aspek pengembangan sumber daya manusia yang transformatif, yang menjadikan pendidikan sebagai motor penggerak perubahan dari masyarakat berkembang menuju masyarakat maju. Pembentukan masyarakat maju selalu diikuti oleh proses tranformasi struktural, yang menandai suatu perubahan dari masyarakat yang potensi sumber daya manusianya kurang berkembang menuju masyarakat yang maju dan berkembang mengaktualisasikan potensi sumber daya manusianya secara optimal.

Yang dimaksud dengan Masyarakat Majalangka Yang Cerdas adalah masyarakat yang cerdas yang secara 
komprehensif, yang meliputi cerdas spiritual, cerdas emosional, cerdas sosial, cerdas intelektual dan cerdas kinestitetis.

\section{B. Misi}

Untuk mencapai Visi tersebut, maka Dinas Pendidikan Kabupaten Majalengka menetapkan Misi Dinas sebagai berikut:

1. Memperluas akses bagi seluruh masyarakat Kabupaten Majalengka baik laki-laki maupun perempuan untuk memiliki kesempatan mendapatkan layanan pendidikan formal dan pendidikan non formal yang bermutu dan relevan dengan kebutuhan masyarakat lokal dan global serta mengacu kepada Standar Nasional Pendidikan,

2. Melaksanakan efisiensi dan efektifitas manajemen pelayanan pendidikan melalui peningkatan pelaksanaan manajemen berbasis sekolah, peran serta masyarakat dalam pembangunan pendidikan, serta efektivitas pelaksanaan otonomi dan desentralisasi pendidikan;

3. Mewujudkan masyarakat pendidikan yang religius, maju dan sejahtera berbasis pengetahuan sehingga bermanfaat untuk pembangunan dan karakter masyarakat Kabupaten Majalengka meningkat.

Sedangkan tugas pokok dan fungsi Dinas Pendidikan Kabupaten Majalengka adalah sebagai berikut : "Dinas Pendidikan mempunyai tugas pokok merumuskan, menyelenggarakan, membina dan mengevaluasi urusan pemerintahan daerah berdasarkan asas desentralisasi dan tugas pembantuan pada bidang pendidikan."

\section{Analisis Sistem}

Analisis sistem adalah penguraian dari suatu sistem informasi yang utuh ke dalam bagian-bagian komponennya dengan maksud untuk mengidentifikasikan dan mengevaluasi permasalahan-permasalahan, kesempatan-kesempatan, hambatanhambatan yang terjadi dan kebutuhankebutuhan yang diharapkan sehingga dapat diusulkan perbaikan-perbaikannya.

Analisis sistem bertujuan untuk mempelajari aktivitas sistem untuk mendapat gambaran yang menyeluruh tentang sistem yang sedang berjalan dan permasalahan yang terjadi serta kebutuhankebutuhannya.

\section{Analisis Sistem Yang Sedang Berjalan}

Analisis sistem merupakan suatu kegiatan untuk mempelajari, mengevaluasi untuk mendapatkan gambaran yang menyeluruh dari sistem. Dalam analisis sistem akan ditemukan masalah yang mungkin akan mempengaruhi kerja sistem. Dengan demikian sistem yang akan dirancang dapat berjalan sebagaimana tujuannya, maka perlu adanya analisis sistem yang sedang berjalan untuk pengembangan sistem.

Berdasarkan apa yang ada dilapangan sistem yang sedang berjalan telah menggunakan komputer akan tetapi belum secara maksimal. Karena dalam pengolahan data masih menggunakan aplikasi Microsoft Office seperti Microsoft Excel untuk mendapatkan hasil diperlukan formula, pencarian data nilai siswa membutuhkan waktu yang cukup lama, data berupa kertas rentan menyebabkan rusak. Hal ini menjadi salah satu penyebab dalam proses pelayanan terhadap siswa dan pihak yang membutuhkan kurang efisien.

\section{E. Analisis Prosedur yang Berjalan}

Sebelum melalui perancangan sistem terlebih dahulu akan dijelaskan dari analisis prosedure sistem yang sedang berjalan. Sistem yang berjalan ini merupakan kumpulan dari proses dalam suatu sistem yang sedang terkait antara satu dengan yang lainnya untuk mencapai tujuan yang telah ditetapkan.

Adapun sistem prosedur tersebut dapat dijelaskan sebagai berikut: 
1. Wali kelas melakukan pencatatan data seluruh nilai siswa kedalam buku leger.

2. Wali kelas mengisikan nilai siswa kedalam buku raport masing-masing siswa yang dilihat dari buku leger.

3. Wali kelas menyerahkan buku raport siswa yang telah diisi nilai siswa kepada Kepala Sekolah untuk diberikan tanda tangan yang sebelumnya sudah ditandatangani oleh wali kelas.

4. Kepala Sekolah melakukan pengesahan dengan memberikan tanda tangan raport tersebut dan diserahkan lagi ke Wali kelas.

5. Wali kelas menyerahkan buku raport tersebut kepada siswa yang bersangkutan.

Untuk lebih jelas dapat dilihat pada flow map prosedur yang sedang berjalan sebagai berikut:

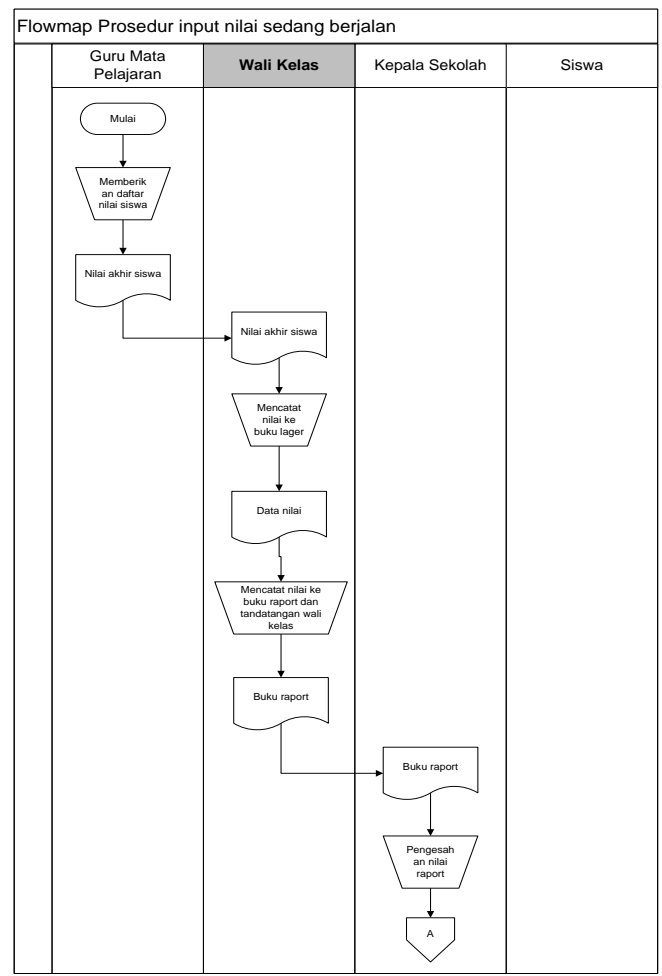

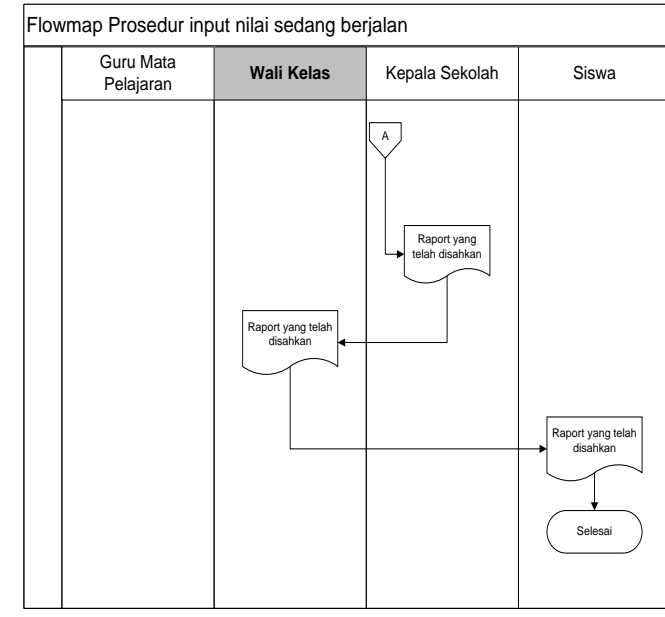

Diagram 1: Flow Map sedang Berjalan

\section{F. Analisis Dokumen}

Dokumen input dan output yang dibutuhkan untuk informasi nilai siswa adalah sebagai berikut:

Nama Dokumen : data siswa

Fungsi : Sebagai data siswa utama

Atribut : NIS, Nama Siswa, Tahun Masuk, Kelas, Tingkat, TTL, Alamat, Jenis kelamin, Agama, Anak ke, Nama Ayah, Nama Ibu, Alamat Orangtua, Pekerjaan

Nama Dokumen : data nilai

Fungsi : dokumen berisi data nilai akhir siswa

Atribut : NIS, Nama Siswa, Kelas, Wali kelas, Nilai

\section{G. Evaluasi Masalah Sistem yang Sedang Berjalan}

Hasil dari evaluasi sistem yang sedang berjalan di SD di Kabupaten Majalengka, yaitu mendapatkan suatu kekurangan dalam pengolahan data nilai diantaranya:

1.pengolahan data nilai siswa menggunakan aplikasi yang sederhana seperti Microsoft Office.

2. Memerlukan tempat yang besar, mengingat siswa yang semakin tahun meningkat

3. Pengamanan data kurang, sistem yang manual memungkin siapa saja dapat memanipulasi data tersebut. 


\section{H. Usulan Penyelesaian Masalah Sistem yang Sedang Berjalan}

Dari kekurangan sistem yang telah disebutkan, maka sebagai usulan sistem baru yaitu dengan mengkomputerisasikan yaitu aplikasi rekap nilai siswa sebagai alternatif dari kekurangan yang telah disebutkan.

Adapun keuntungan dari sistem usulan tersebut adalah sebagai berikut :

1. Tidak memerlukan tempat yang besar

2. Biaya yang dikeluarkan tidak terlalu besar, mengingat sudah terdapat perangkat yang diperlukan.

3. Pengendalian mudah, hanya orang tertentu yang dapat mengakses sistem sehingga meminimalisir adanya manipulasi data.

\section{Prosedur Usulan Sistem}

Dari hasil analisis sistem yang sedang berjalan, didapat sebuah prosedur usulan sistem yaitu sebagai berikut :

1. Guru mata pelajaran menyerahkan nilai akhir siswa kepada wali kelas

2. Admin menginputkan nilai akhir siswa kedalam database

3. Kemudian diakumulasikan oleh sistem dan menjadi nilai raport siswa.

4. Kemudian nilai akhir secara otomatis terpublikasikan oleh sistem berupa nilai raport siswa.

\section{PERANCANGAN}

Pada tahap ini akan penulis paparkan mengenai rancangan dari aplikasi yang akan dibuat, yaitu sebagai berikut :

\section{A. Diagram Konteks}

Diagram konteks merupakan diagram yang menunjukan arus data baik yang mengarah (input) maupun arus data keluar (output) dari terminator DFD (Data Flow Diagram)

DFD (Data Flow Diagram) adalah penyajian grafis dari sebuah sistem yang mempergunakan empat bentuk simbol untuk mengilustrasikan bagaimana data mengalir melalui proses-proses yang saling tersambung. Simbol-simbol tersebut mencerminkan : unsurunsur lingkungan dengan nama sistem berinteraksi, proses, arus data, dan penyimpanan data.

Tabel 1; DFD Level 1

\begin{tabular}{|c|ll|lr|}
\hline No. & \multicolumn{1}{|c|}{ Proses } & \multicolumn{2}{|c|}{ Keterangan } \\
\hline 1 & Login & $\begin{array}{l}\text { Proses login } \\
\text { merupakan proses } \\
\text { dimana rana } \\
\text { menginput username } \\
\text { dan password untuk } \\
\text { masuk kedalam } \\
\text { sistem }\end{array}$ \\
\hline 2 & $\begin{array}{l}\text { Input } \\
\text { Siswa }\end{array}$ & Data & $\begin{array}{l}\text { Proses input data } \\
\text { siswa adalah proses } \\
\text { dimana wali kelas } \\
\text { menginputkan data } \\
\text { siswa }\end{array}$ \\
\hline 3 & $\begin{array}{l}\text { Input } \\
\text { Nilai }\end{array}$ & Data & $\begin{array}{l}\text { Proses input data } \\
\text { siswa adalah proses } \\
\text { dimana wali kelas } \\
\text { menginputkan data } \\
\text { nilai siswa }\end{array}$ \\
\hline
\end{tabular}

\section{B. Deskripsi File}

Berikut deskripsi file tempat penyimpanan data :

Tabel 2 Deskripsi File

\begin{tabular}{|c|l|l|}
\hline No. & \multicolumn{1}{|c|}{ File } & \multicolumn{1}{|c|}{ Keterangan } \\
\hline 1 & user & $\begin{array}{l}\text { File yang berfungsi untuk } \\
\text { menyimpan data user }\end{array}$ \\
\hline 2 & siswa & $\begin{array}{l}\text { File yang berfungsi untuk } \\
\text { menyimpan data siswa }\end{array}$ \\
\hline 3 & nilai & $\begin{array}{l}\text { File yang berfungsi untuk } \\
\text { menyimpan data nilai }\end{array}$ \\
\hline
\end{tabular}

\section{Perancangan Basis Data}

\section{ERD (Entity Relationship Diagaram)}

Entity Relationship Diagram merupakan gambaran relasi antar field atau tabel, dapat digolongkan kedalam tiga macam bentuk relasi. Yaitu relasi dari satu kesatu, satu kebanyak, banyak kebanyak.

\section{Kamus Data}

Kamus data (data dictionary) adalah kumpulan elemen-elemen atau simbol-simbol yang digunakan untuk membantu dalam penggambaran atau pengindentifikasian setiap filed atau file dalam system. Kamus data dari aplikasi yang dibuat adalah sebagi berikut :

siswa $=$ nis + nama_siswa + thn_masuk 
+ kelas + alamat $+\mathrm{tl}+\mathrm{dd}+\mathrm{mm}$ $+\mathrm{yy}+$ agama $+\mathrm{jk}+$ anak_ke + nama_ayah + nama_ibu + alamat_ortu + pekerjaan + status_kel

nilai $=\mathrm{nis}+$ semester $+\mathrm{ctt}+\mathrm{wk}+$ kepsek + wnip + knip + rt_rt2 + jml2 + pel1 + Pel2 + Pel3 + Pel $4+$ Pel5 + Pel6 + Pel $7+$ Pel $8+$ Pel9 + Pel10

user $=$ norut + username + password

\section{Struktur Tabel}

Struktur file merupakan tabel yang ada didalam database, berikut ini merupakan tabel yang ada dalam sistem yang dibuat :

1. Tabel Siswa

Tabel 3: Data Siswa

\begin{tabular}{|l|l|l|l|}
\hline Field Name & $\begin{array}{c}\text { Type } \\
\text { Data }\end{array}$ & Size & \multicolumn{1}{|c|}{ Deskripsi } \\
\hline nis & Int & 20 & $\begin{array}{l}\text { Nomor induk } \\
\text { siswa, Primary } \\
\text { key }\end{array}$ \\
\hline nama_siswa & varchar & 30 & Nama siswa \\
\hline thn_masuk & Int & 4 & Tahun masuk \\
\hline kelas & varchar & 10 & Kelas \\
\hline alamat & varchar & 100 & alamat \\
\hline tl & varchar & 30 & Tempat lahir \\
\hline dd & Int & 2 & Tanggal \\
\hline mm & Int & 20 & Bulan \\
\hline yy & Int & 4 & tahun \\
\hline agama & varchar & 20 & Agama \\
\hline jk & varchar & 10 & Jenis kelamin \\
\hline anak_ke & int & 5 & Anak ke \\
\hline nama_ayah & varchar & 50 & Nama ayah \\
\hline nama_ibu & varchar & 50 & Nama ibu \\
\hline alamat_ortu & varchar & 100 & $\begin{array}{l}\text { Alamat oran } \\
\text { tua }\end{array}$ \\
\hline pekerjaan & varchar & 30 & Pekerjaan \\
\hline status_kel & varchar & 20 & Status keluarga \\
\hline
\end{tabular}

2. Tabel Nilai

Tabel Nilai Siswa

\begin{tabular}{|l|l|l|l|}
\hline $\begin{array}{c}\text { Field } \\
\text { Name }\end{array}$ & \multicolumn{1}{|c|}{$\begin{array}{c}\text { Type } \\
\text { Data }\end{array}$} & Size & \multicolumn{1}{|c|}{ Deskripsi } \\
\hline nis & Int & 20 & $\begin{array}{l}\text { Nomor induk } \\
\text { siswa, } \\
\text { Primary key }\end{array}$ \\
\hline semester & varchar & 1 & Semester \\
\hline ctt & varchar & 100 & catatan \\
\hline wk & varchar & 30 & Wali kelas \\
\hline kepsek & varchar & 30 & $\begin{array}{l}\text { Kepala } \\
\text { sekolah }\end{array}$ \\
\hline
\end{tabular}

\begin{tabular}{|l|l|l|l|}
\hline $\begin{array}{c}\text { Field } \\
\text { Name }\end{array}$ & \multicolumn{1}{|c|}{$\begin{array}{c}\text { Type } \\
\text { Data }\end{array}$} & Size & \multicolumn{1}{|c|}{ Deskripsi } \\
\hline wnip & text & 30 & $\begin{array}{l}\text { NIP untuk } \\
\text { wali kelas }\end{array}$ \\
\hline knip & text & 30 & $\begin{array}{l}\text { NIP untuk } \\
\text { kepala } \\
\text { sekolah }\end{array}$ \\
\hline rt_rt2 & decimal & 5 & Rata-rata \\
\hline jml2 & decimal & 5 & jumlah \\
\hline Pel1 & float & 5 & $\begin{array}{l}\text { Pendidikan } \\
\text { agama islam }\end{array}$ \\
\hline Pel2 & float & 5 & $\begin{array}{l}\text { Pendidikan } \\
\text { kewarganegar } \\
\text { aan }\end{array}$ \\
\hline Pel3 & float & 5 & Matematika \\
\hline Pel4 & float & 5 & $\begin{array}{l}\text { Bahasa } \\
\text { Indonesia }\end{array}$ \\
\hline Pel5 & float & 5 & PJOK \\
\hline Pel6 & float & 5 & $\begin{array}{l}\text { SBDP / } \\
\text { Kesenian }\end{array}$ \\
\hline Pel7 & float & 5 & IPA \\
\hline Pel8 & float & 5 & IPS \\
\hline Pel9 & float & 5 & Bahasa Sunda \\
\hline Pel10 & float & 5 & $\begin{array}{l}\text { Bahasa } \\
\text { Inggris }\end{array}$ \\
\hline
\end{tabular}

3. Tabel User

Tabel User Data Siswa

\begin{tabular}{|l|l|l|l|}
\hline $\begin{array}{c}\text { Field } \\
\text { Name }\end{array}$ & $\begin{array}{c}\text { Type } \\
\text { Data }\end{array}$ & Size & Deskripsi \\
\hline norut & int & 3 & $\begin{array}{l}\text { Nomor } \\
\text { urut, } \\
\text { Primary } \\
\text { key }\end{array}$ \\
\hline username & varchar & 10 & Username \\
\hline password & varchar & 10 & Password \\
\hline
\end{tabular}

\section{Perancangan Antar Muka}

Merancang antar muka merupakan bagian yang penting dari merancang sistem. Bagian ini pula kadang membuat dilema perancang sistem karena dalam merancang antar muka sistem harus memenuhi tiga persyaratan : sebuah antar muka harus sederhana, lengkap dan sebuah antar muka harus memiliki kinerja yang cepat.

\section{KESIMPULAN}

\section{A. Kesimpulan}

Beberapa kesimpulan yang dapat penulis buat adalah sebagai berikut :

1. Proses analisis terhadap kegiatan penilaian hasil pembelajaran siswa dilakukan dengan melihat dokumen penilaian yang ada 
ditambah dengan proses pengumpulan data yang berasal dari dinas pendidikan dan kemendikbud serta dari beberapa orang guru.

2. Perancangan aplikasi rekap nilai dibuat dengan mempertimbangkan hasil analisis yang sudah dilakukan.

3. Implementasi pembuatan aplikasi dibuat dengan memperhatikan kegiatan analisis dan kegiatan perancangan yang dilakukan oleh penulis pada tahapan sebelumnya.

\section{B. Saran}

1. Hendaknya kepada setiap sekolah memberikan pelatihan khusus kepada guru mengenai penggunaan komputer untuk menunjang kegiatan penilaian siswa di kelas.

2. Hasil dari penulisan artikel ini dapat dikembangkan lagi lebih jauh oleh pihakpihak yang tertarik untuk melakukan pengembangan.

\section{DAFTAR PUSTAKA}

1. [BON08]Bonnie Soeherman \& $\mathrm{M}$. Pinontoan, Designing information

2. system, Elex Media Komputindo, Jakarta, 2008

3. [HAR]Hartati, Sri S.Kom. Modul Analisis Sistem Informasi : Akmi Baturaja

4. [KUS06]Kuswayanto, Lia. 2006. Mahir dan Trampil Berkomputer. PT.Grapindo Media Pratama

5. [AND]Andi, Pengenalan Sistem Informasi, Penerbit Andi Yogyakarta.

6. http://blog.binadarma.ac.id/usman/? $p=942$

7. http://elib.unikom.ac.id

8. http://trisnowlaharwetan.wordpress.com/20 10/02/07/waterfall-sebagai-modelrekayasa-perangkat-lunak/

9. http://id.shvoong.com/writing-andspeaking/2045907-analisissistem/\#ixzzliJPP7bwk

10. http://pckom.blogspot.com/2009/06/normal isasi-dan-kamus-data.html 